\title{
STATUTORY OF THE REPUBLIC OF INDONESIA WITNESS AS A GOVERNMENT INSTITUTION IMPLEMENTING COUNTRY'S POWER IN THE INDONESIAN STATE CONCERNS SYSTEM
}

\author{
${ }^{1}$ Janpatar Simamora \\ Universitas HKBP Nommensen Medan \\ e-mail: patarmora@yahoo.com \\ ${ }^{2}$ Bintang ME Naibaho \\ Universitas HKBP Nommensen Medan
}

\begin{abstract}
The Attorney General's Office of the Republic of Indonesia is a government agency that exercises state power in the field of law enforcement, particularly in the field of prosecution. As a law enforcement agency that has a central role in the legal process itself, the Attorney General's Office of the Republic of Indonesia can be positioned as part of the main state institutions that have the same position and presence as other main state institutions. But in its implementation, the position of the Attorney General's Office of the Republic of Indonesia was not always in line with the main tasks it was carrying. Moreover, the regulation in the 1945 Constitution of the Republic of Indonesia as a state constitution was not found at all. In the relation of it, this research is intended in order to find out the position of the Attorney General's Office of the Republic of Indonesia as a government agency implementing state power in the Indonesian constitutional system. In order to answer the problems in this study, normative juridical research methods are used, namely by examining various existing provisions as secondary data to solve the problem under study. The results of this study indicate that the position of the Attorney General's Office of the Republic of Indonesia as a government agency implementing state power is a law enforcement agency that is placed as part of the executive, but the implementation of the main duties and functions as well as its authority falls within the judicial realm. Based on such conditions, further regulation is needed regarding the position of the Attorney General's Office of the Republic of Indonesia which is more ideal, so that in carrying out its main duties and functions as well as its authority can run well.
\end{abstract}

Keywords: Attorney General's Office, state institution, constitution, independence, state administration.

\section{INTRODUCTION}

Referring to Act Number 16 of 2004 concerning the Attorney General's Office of the Republic of Indonesia, the Attorney General's Office of the Republic of Indonesia is a government agency that exercises state power in the field of prosecution as well as other authorities based on the law. Furthermore, the prosecution is interpreted as an act of public prosecutor in order to submit the case to the district court in charge of matters and according to the mechanism stipulated in the Criminal Procedure Code with a request that an investigation be carried out and subsequently decided by a judge in a court session. Based on these provisions, it is clear how important the position of the Attorney General's Office of the Republic of Indonesia is in the process of law enforcement. If we probe from the perspective of constitutional provisions which affirm that the state of Indonesia as a state of law, then the basis for the establishment and formation of the Attorney General's Office of the Republic of Indonesia cannot be separated from the parts and efforts to realize one of the constitutional norms, namely the realization of the rule of law. The rule of law itself can be interpreted as general aspirations as a prerequisite for 
realizing modern governance. This can be seen from the opinion expressed by Kirby (2010: 1) by saying that The rule of law is a common aspiration proclaimed by international organizations and national governments, as a pre-condition for acceptable modern governance. Even in the context of law enforcement, the Attorney General's Office of the Republic of Indonesia can also be interpreted as the main state institution which is as strong and important as the other main state institutions. The Attorney General's Office of the Republic of Indonesia plays a major role in determining the direction of law enforcement through the application of basic tasks and functions carried out in the Indonesian law enforcement system. The rule of law itself as part of efforts to prevent the emergence of arbitrariness in the exercise of state power, because after all arbitrary choices are commonly thought to be inimical to the rule of law (James A Grant, 2017: 383).

On the other hand, if there is an in-depth analysis of the provisions in the constitution, the Republic of Indonesia's Attorney General's Office will not be found in the articles contained in the constitution. It means, the regulation of the Attorney General's Office was not found explicitly in the 1945 Constitution of the Republic of Indonesia. The only norm that could be drawn as a basis for the formation of a Attorney General's Office through the constitution was only possible through section 24 paragraph (3) of the 1945 Constitution of the Republic of Indonesia. The Republic of Indonesia Attorney General's Office, which was later regulated through Law Number 16 of 2004, seeks to translate the intent of Section 24 paragraph (3) of the 1945 Constitution of the Republic of Indonesia as part of the efforts to establish a law enforcement agency in general, including the establishment of a Republic of Indonesia Attorney General's Office. Then if it refers to the provisions in Act Number 16 of 2004, then the position of the Attorney General's Office of the Republic of Indonesia is under the executive authority with the level of position following the division of administrative territory. The Attorney General's Office is located in the National Capital, the Attorney General's Office is in the province and the District Attorney's Office is in the district / city area. The authority enforcement of each of the prosecutors is based on the division of administrative areas of government.

Considering that the implementation of the main duties, functions and authority of the Attorney General's Office is the applicator of law enforcement, then furthermore in the intended implementation, the Attorney General's Office enters the domain of judicial power. The Attorney General's Office in the constitutional system of the Republic of Indonesia acts as a public prosecutor in various criminal cases with a position as a representative of the state and society in general and also a state attorney's attorney in civil cases and state administration. Referring to such a position, it can be said that the Prosecutors' Office actually has a strategic role in the process of law enforcement and even participates in determining the direction of law enforcement itself through the performance it carries out. In order to guarantee the implementation of the strategic role referred to, the Attorney General's Office is expected to be able to work independently and independently and be independent from any power. Through this regulatory model, the implementation of state power in the field of law enforcement can run professionally and be able to meet the objectives of law enforcement itself. However, given that the Prosecutors' Office is in the realm of executive power, efforts to realize independence, independence and even independence in the process of law enforcement, especially prosecution, are difficult to realize. When the Attorney General's Office is under executive power, it will actually be rigorous for the Attorney General's Office to free from the influence and intervention of executive power. The president as the highest holder of executive power is feared that it will be so easy to intervene in the implementation of law enforcement by the Attorney General's Office. This is what then needs to be studied further through efforts to examine the position of the Attorney General's Office in the law enforcement system that is run in the country. 


\section{RESEARCH METHODS}

This research is a normative legal research. Considering that this research is a normative juridical study, the main study of this study is to use secondary data as the main study material. The secondary data consists of primary legal materials, secondary legal materials and tertiary legal materials. The legal material is used proportionally according to the level of research needs. Furthermore, data analysis is carried out in the framework of processing and systematizing available legal materials. The research data were analyzed qualitatively according to the problem and based on the existing theoretical framework. The analysis process is carried out through an inventory of various existing provisions and then related to the position of the Attorney General's Office of the Republic of Indonesia as a government agency implementing state power. This activity is intended in order to further examine the law as an aspired (das sollen) to then compare it with an actual legal condition (das sein) (Janpatar Simamora, 2013: 392). Through this process, it is expected that a conclusion will be born that leads to efforts to improve the position of the Attorney General's Office of the Republic of Indonesia in the context of carrying out its main tasks and functions and authorities.

\section{DISCUSSION}

The country of Indonesia is a country of law. This is confirmed in section 1 paragraph (3) of the 1945 Constitution of the Republic of Indonesia. As a consequence of the adoption of a state of law for the Indonesian nation, all state and government activities must truly refer to existing legal rules. The emergence of ideas and thoughts of the rule of law is inseparable from the pattern of implementing state power that is vulnerable to arbitrary acts, so it is necessary to limit state power through legal instruments (Janpatar Simamora, 2014: 4). Meyerson (2004: 1) argues that the rule of law is the opposite of the rule of power. It stands for the supremacy of law over the supremacy of individual will. Based on the historical emergence of thoughts about the rule of law, various terms such as the rule of law, rechtsstaat and etat de droit are found. Nevertheless, the understanding and characteristics of the rule of law as raised through the term referred to always lead to the view that concludes that the rule of law is a state that bases all aspects of state life on clear and firm legal mechanisms (Janpatar Simamora, 2014: 552). The concept of the rule of law feels increasingly prominent along with the development of democracy in various parts of the world. In practice then, the rule of law and democracy are considered as two complementary parts in the exercise of state power. Lord Bingham (2007: 84) argues that there has been much debate whether the rule of law can exist without democracy. The rule of law depends on an unspoken but fundamental bargain between the individual and the state, the governed and the governor, by which both sacrifice a measure of freedom and power which they would otherwise enjoy.

Certainly, the implementation and enforcement of the law will be fulfilled properly if the state has the equipment that runs the law enforcement itself. One of the law enforcement agencies established by the state is the Attorney General's Office of the Republic of Indonesia. In addition, the state through a number of other regulations also helped establish judicial institutions and lawyers to complement each other in the law enforcement process itself. The Attorney General's Office of the Republic of Indonesia as one of the law enforcement agencies has a major role in upholding the rule of law, protecting the rights of citizens including eradicating corruption, collusion and nepotism as well as various other crimes that have been categorized as extraordinary crimes. Even in every law enforcement process, the role and function of the Attorney General's Office is needed through the prosecution authority inherent in the said institution.

The only institution that holds the prosecution function in the law enforcement process so far is only attached to the Attorney General's Office. The function is enough to show how urgent the Prosecutor's position is in the field of law enforcement. Of course it can be imagined how the fate of law enforcement without being supported by the existence of the Attorney General's Office itself. The legal process in the judiciary will experience inequality without the presence of prosecutors in the prosecution process. This also makes each country always establish a Attorney General's Office within the scope of law 
enforcement in each country. Therefore it becomes very reasonable if then there are many parties who always give the spotlight and even participate in overseeing the performance of the Attorney General's Office in the exercise of his authority. This is understandable given the level of success of law enforcement will also be very much influenced by the performance of the Attorney General's Office itself. Such great public attention to the Attorney General's Office must be placed as part of the efforts of the wider community to maintain the Prosecutor's reputation and image in the future.

Considering to the enormous role of the Attorney General's Office in the process of law enforcement, efforts to arrange the position of the Attorney General's Office as an institution that carries out state power are urgently needed. Even though the Attorney General's Office is given a considerable amount of authority, if it is not balanced with a truly qualified position, this will not be able to produce a major change for the future of law enforcement. Institutionally, the Prosecutors' Office is under executive authority. This means that the Prosecutors' Office will find it difficult to become an independent institution because it is still entirely possible to be controlled by a higher power hierarchy. While on the other hand, the state requires the implementation of a prosecutor's performance that is truly independent and independent and free from any influence of power. The implementation of the duties and functions as well as the authority of the Attorney General's Office that intersects with the judiciary authority must make the Attorney General's Office truly independent.

As is known in the theory of trias politica Mostesquieu popularized that one of the main principles as well as what distinguishes judicial power from other powers lies in its independence. In line with that, given that the implementation of the prosecutor's authority is closely related to judicial power, the Attorney General's Office must also be able to work independently and independently and objectively. The Prosecutors' Office must be able to work independently even if it is under executive authority. This has become a serious challenge for the Attorney General's Office with the current model. The challenge is felt when faced with the political interests of the executive power holders. However, it is also possible that the executive power holders will intervene in the Prosecutor's performance. This is possible because the Prosecutor's position is institutionally under the authority of the president as the highest holder of executive power. It must be admitted that the effort to realize the ideals of the rule of law is not an easy task. There are various challenges and obstacles in realizing the implementation of the governmental wheel based on legal mechanisms. As stated by Robert Stein, (2009: 303) that the rule of law in the purist sense, is an ideal, a goal, something to be strived for. As an ideal, it is never fully achieved. Its presence or absence should be judged in relative terms; what is possible in an advanced western democracy may not be possible in a developing nation. No country may rightfully claim perfect adherence to these ideas. Nevertheless, as a country that continues to improve in order to improve the enforcement mechanism for the rule of law, the structuring of the position of the Attorney General's Office of the Republic of Indonesia needs to be formulated in such a way as to effectively implement the Attorney's authority in the future. Efforts to formulate a more ideal position of the Attorney General's Office by reflecting independence, independence and independence in carrying out their duties and authorities can be done by placing the Attorney General's Office as an independent institution, both from an institutional standpoint and from the standpoint of the authority it possesses. Through this form of regulation, it is hoped that the implementation of the Attorney's tasks and authorities will be able to run professionally and better.

\section{CONCLUSION}

Based on the results of the research as described above, it can be concluded that the position of the Attorney General's Office of the Republic of Indonesia as a government agency implementing state power is a law enforcement agency that is placed as part of the executive power, but the implementation of basic tasks and functions as well as its authority falls within the realm of judicial power. This shows the ambiguity in the regulation of the Prosecutor's position as a law enforcement agency. In addition, the placement of the Attorney General's Office as part of executive power will conflict with the implementation of his main duties and functions as well as his authority which demands to be carried out 
independently and free from any authority. The Attorney General's Office of the Republic of Indonesia as an independent and independent institution in carrying out its duties will be difficult to realize as long as its position is still part of the executive power. Therefore, further regulation is needed regarding the position of the Attorney General's Office of the Republic of Indonesia which is more ideal, namely by placing the Attorney General's Office as an independent, independent and independent institution, both in terms of institutional and authority, so that in carrying out its main tasks and functions as well as its authority can run well especially in the context of law enforcement which truly reflects the achievement of the main pillars of the objectives of law enforcement itself.

\section{REFERENCES}

Denise Meyerson, The Rule of Law and The Separation of Powers, Macquarie Law Journal, Volume 4, Number 1, 2004, page 1-6.

James A Grant, The Ideals of the Rule of Law, Oxford Journal of Legal Studies, Volume 37, Issue 2, Summer 2017, pages. 383-405.

Janpatar Simamora, Tafsir Makna Negara Hukum dalam Perspektif Undang-Undang Dasar Negara Republik Indonesia Tahun 1945, Jurnal Dinamika Hukum, Volume 14 Nomor 3 September 2014, page 547-561.

Janpatar Simamora, Kepastian Hukum Pengajuan Kasasi oleh Jaksa Penuntut Umum Terhadap Vonis Bebas, Jurnal Yudisial, Komisi Yudisial RI, Volume 7 Nomor 1 April 2014, page 1-17.

Janpatar Simamora, Analisa Yuridis Terhadap Model Kewenangan Judicial Review di Indonesia, Jurnal Mimbar Hukum FH UGM, Volume 25 Nomor 3 Oktober 2013, page 389-401.

Lord Bingham, The Rule of Law, The Cambridge Law Journal, Volume 66 Issue 1, March 2007, page. $67-85$.

Michael Kirby, The Rule of Law Beyond The Law of Rules, Article for Australian Bar Review Based on part of address to 15th Malaysian Bar Association Conference, Kuala Lumpur, 29 July 2010.

Robert Stein, Rule of Law: What Doesn it Mean?, 18 Minn. J. Int'l L. 293 (2009), available at http://scholarship.law.umn.edu/ faculty_articles/424. 